\title{
Focal dermal hypoplasia
}

INSERM

\section{Source}

INSERM. (1999). Orphanet: an online rare disease and orphan drug data base. Focal dermal hypoplasia. ORPHA:2092

A rare multiple congenital anomalies/dysmorphic syndrome characterized by abnormalities in ectodermal- and mesodermal-derived tissues, classically manifesting with skin abnormalities, limb defects, ocular malformations, and mild facial dysmorphism. 